Щоденно увечері всі учасники інтенсиву відвідують так звані процесгрупи, на яких можуть доопрацювати незавершені на денних групах акції та виявити свої почуття з приводу того, що відбувається.

Немало позитивних наслідків має і неформальне спілкування з викладачами, тренерами, психотерапевтами, можливість поставити їм запитання, звернутися з проблемою, зрештою - просто спостерігати за ними.

Висновки і перспективи подальших досліджень. Під час проходження виробничої практики студенти соціономічних професій загалом і майбутні медичні психологи зокрема одночасно можуть і відпрацьовувати уміння та навички, і спостерігати за роботою досвідчених фахівців, i адаптуватись до умов конкретного робочого місця. Крім того, виробнича практика дає студентам можливість не лише отримати оцінку відповідно до рівня засвоєння знань та оволодіння уміннями та навичками, а й отримати зворотний зв'язок від діючих професіоналів. Виробнича практика, як перший досвід наближення студента до самостійної професійної діяльності, є надзвичайно важливим чинником становлення майбутнього професіонала. Перспективою подальших досліджень є розробка та впровадження тренінгових програм, спрямованих на формування комунікативних якостей фахівців соціономічних професій.

1. Борисюк А. С. Професійна ідентичність медичного психолога : монографія. Чернівці, 2010. $440 \mathrm{c}$.

2. Исаев Е. И., Косарецкий С. Г., Слободчиков В. И. Становление и развитие профессионального сознания будущего педагога. Вопросы психологии. 2000. № 3. С. 58-67.

3. Максименко С. Д., Борисюк А. С. Значення навчально-виробничої практики в професійному становленні майбутнього лікаря-психолога. Підготовка лікарів-психологів : сучасний стан, перспективи, тенденції: матеріали Всеукраїнської науково-методичної конференції (м. Чернівці, 13-14 травня 2005 р.). Чернівці : Медуніверситет, 2005. С. 13-15.

УДК 159.9: 355.1/.2

doi: $10.15330 / p s p .22 .106-115$

Олександра Гринчук

\title{
ПСИХОЛОГІЧНА ГОТОВНОСТЬ МАЙБУТНІХ ОФІЦЕРІВ-ПСИХОЛОГІВ ДО ПРОФЕСІЙНОЇ ДІЯЛЬНОСТІ: ОСНОВНІ КРИТЕРІЇ ТА ПОКАЗНИКИ
}

У статті проаналізовано теоретичні підходи до проблеми формування психологічної готовності офіиерів-психологів до професійної діяльності. Відзначено доиільність застосування інтегративного підходу до проблеми формування психологічної готовності до професії. В якому виокремлено особистісну, функиіональну та спеціальну готовність. Проаналізовано особливості вивчення критеріїв готовності до професійної діяльності в сучасній науці. Визначено та обтрунтовано основні критерії та показники психологічної готовності майбутніх офіцерів-психологів до здійснення професійної діяльності.

Ключові слова: психологічна готовність, професійна діяльність, професійні якості, компетентність, показники психологічної готовності, критерій. 
The article analyzes theoretical approaches to the problem of formation of psychological readiness of officers-psychologists to professional activity. The expediency of using an integrative approach to the problem of formation of psychological readiness for a profession is noted. In which the personal, functional and special readiness are singled out. Peculiarities of the study of criteria of readiness for professional activity in modern science are analyzed. The main criteria and indicators of psychological readiness of future officers-psychologists for professional activity are determined and substantiated.

Keywords: psychological readiness, professional activity, professional qualities, competence, indicators of psychological readiness, criterion.

Актуальність дослідження. Сучасне реформування Збройних сил України, стратегічні виклики національній безпеці та обороні зумовили нагальну потребу у професійній підготовці кваліфікованих офіцерів-психологів, здатних ефективно виконувати завдання психологічної підготовки та супроводу військовослужбовців у мирний та військовий час.

Вимоги які висувають сучасні реалії до фахівців такої категорії дуже високі, а надто, якщо це стосується військової сфери. Адже професійна діяльність офіцера-психолога вимагає не лише фахової підготовки, професійної майстерності, а й наявності соціально значущих та професійно важливих якостей особистості.

Особливостями вимог до таких фахівців $є$ те, що наявність розвитку певних якостей особистості не зумовлена лише зовнішніми умовами, а виступає, найважливішим компонентом і показником успішності реалізації їх у професії. Іншими словами, формування готовності до професійної діяльності виступає ядром їх професійної спрямованості. Тому, дослідження критеріїв психологічної готовності майбутніх офіцерів-психологів до виконання професійної діяльності є надзвичайно актуальним.

Аналіз останніх досліджень. На сьогодні наука містить значний теоретичний та практичний доробок щодо проблеми готовності людини до професійної діяльності. Дослідженням питань формування психологічної готовності до професійної діяльності займались М. Варій, М. Головін, М. Дьяченко, Л. Кандибович, Л. Карамушка, В. Кожевніков, О. Колісніченко, В. Кремень, С. Максименко, Л. Балабанова, А. Деркач, В. Рибалка та ін.; психологічної готовності військовослужбовця до діяльності в екстремальних та бойових умовах В. Ягупов, Р. Абдурахманова, А. Анцупова, В. Барабанщікова, Ю. Зуєва, О. Караяні, П. Корчемний, Г. Гребенюк, В. Лефтеров, С. Максименко, П. Мельник, Б. Олексієнко та ін. У сучасній психологічній літературі існує низка робіт, предметом дослідження яких є проблеми готовності офіцерів до управлінської діяльності Н. Агаєв, В. Афонін, Я. Бондаренко, В. Говоруха, А. Журавель, В. Журавльов, Д. Завалишина, Н. Іванова, О. Кравченко та ін.; а також проблеми готовності психолога до професійної діяльності М. Дьяченко, Л. Кандибович, М. Левченко, С. Максименко, В. Моляко, Н. Пов'якель, Н. Чепелєва, В. Панок та ін. Однак, питання психологічної готовності майбутніх офіцерів-психологів до виконання професійної діяльності, на сьогодні, залишаються недостатньо вивченими.

Метою статті $\epsilon$ визначення та теоретичне обгрунтування основних критеріїв та показників психологічної готовності майбутніх офіцерів-психологів до професійної діяльності. 
Виклад основних положень. Під психологічною готовністю розуміють психічний стан при якому відбувається мобілізація ресурсів для виконання конкретної діяльності, що дозволяє успішно виконувати свої обов'язки; вдало застосовувати знання, уміння, навички, досвід, мотиви, особистісні якості; зберігати самоконтроль та моделювати діяльність при виникненні труднощів й перешкод для результативного та якісного виконання завдань $[6 ; 7 ; 17 ; 19]$.

Теоретичний аналіз літератури дозволяє виокремити два основні підходи до проблеми формування психологічної готовності до професійної діяльності: функціональний та особистісний $[12 ; 16]$. Це дає підстави розглядати психологічну готовність офіцера-психолога, як результат інтеграції функціональної та особистісної готовності до діяльності в особливих умовах, що є типовим для його професійної діяльності.

Функціональний підхід формування психологічної готовності до професійної діяльності розглядає іiї як певний стан психічних функцій, який забезпечує високий рівень досягнень при виконанні завдань. Даний підхід розглядає психологічну готовність до професійної діяльності як психічний стан, що показує іiї як передстартову активізацію психічних функцій, уміння мобілізувати необхідні фізичні й психічні ресурси для реалізації діяльності.

На думку В. Ягупова такий стан психологічної готовності являє собою спрямованість і мобілізованість психіки військовослужбовця на подолання майбутніх труднощів, що забезпечує результативність і якість виконання поставлених завдань [19].

За визначенням В. Дружиніна психологічна готовність, як психічний стан, характеризується мобілізацією ресурсів суб'єкта на здійснення конкретної діяльності та допомагає успішно виконувати свої обов'язки, правильно використовувати знання, досвід, особистісні якості, зберігати самоконтроль і змінювати діяльність під час виникнення непередбачених перешкод [6].

Згідно особистісного підходу формування психологічної готовності військовослужбовців до професійної діяльності це стійкий комплекс особистісних якостей та властивостей, необхідних для успішної діяльності при виконанні службових завдань.

Головна особливість готовності як стійкої системи якостей особистості полягає в тому, що вона формується заздалегідь. Так, Б. Г. Ананьєв [1] трактує готовність як властивість і якість особистості, спектр іiї професійних здібностей, прояв професійної спрямованості та професійної самосвідомості, стійку характеристику особистості.

Г. Гребенюк розглядає психологічну готовність курсантів вищого військового навчального закладу до професійної діяльності як систему професійноважливих якостей, властивостей особистості, необхідних та достатніх для ефективної професійної діяльності [4].

О. Василенко професійно-психологічну готовність майбутніх працівників ОВС до екстремальних ситуацій визначає як інтегративну якість особистості, що забезпечує стабільну ефективність діяльності в складних стресогенних умовах, адаптивний тип поведінки у службових екстремальних ситуаціях, що дозволяє ефективно виконувати завдання [3]. 
В межах особистісного підходу, готовність до професійної діяльності виступає як інтегральне особистісне утворення, яке має певну структуру, до якої входять такі компоненти: мотиваційний, когнітивний, емоційно-вольовий, операційний, поведінковий, як сукупність особистісних якостей, вмінь, навичок, відповідних вимогам та змісту діяльності. При цьому готовність розглядається як цілеспрямований розвиток особистості в світлі ії поглядів, переконань, мотивів, умінь, інтелектуальних і вольових почуттів, налаштованості на певну поведінку, як сформованість певної системи якостей, властивих тій чи іншій діяльності [12].

Окрім охарактеризованих, у психологічній літературі виділяють також й інші підходи при розгляді готовності до професійної діяльності. Зокрема, компетентнісний підхід, який дозволяє визначити інтелектуальну характеристику суб'єкта залежно від сфери його майбутньої діяльності, синергетичний підхід за допомогою якого можна обгрунтувати можливості самоорганізації у процесі формування готовності, інтегративний - дозволяє вивчати процес об'єднання в ціле окремих елементів, іноді на перший погляд незалежних один від одного, 3 отриманням нових або бажаних властивостей суб'єкта [13].

В межах компетентнісного підходу наголошується на виокремленні військово-спеціальної компетентності, яка розглядається, як інтегральна характеристика офіцера, його визначальна здатність і готовність виконувати посадові обов'язки та вирішувати професійні завдання військово-спеціального характеру, що виникають у реальних ситуаціях професійної діяльності, з використанням відповідних знань, умінь, навичок, професійного і життєвого досвіду, цінностей та культури [18].

Отож, опираючись на вище наведені підходи, психологічна готовність майбутніх офіцерів-психологів до професійної діяльності повинна включати в себе не лише функціональну та особистісну готовність, а й, як мінімум, військову компетентність - як здатність та готовність до виконання спеціальних військових завдань та синергетичну компетентність - можливість самоорганізації, самоконтролю та самоефективності у професійній військовій діяльності.

Відтак, такий компетентнісний підхід до формування психологічної готовності офіцерів-психологів до професійної діяльності дозволить сформувати фахові компетенції, які передбачатимуть наявність професійних знань, умінь, навичок, досвіду не лише в межах психологічної спеціальності, а й у військової сфері для забезпечення ефективної професійної діяльності офіцера-психолога.

Проведений теоретичний аналіз психологічних підходів формування психологічної готовності майбутніх офіцерів-психологів до професійної діяльності дає можливість стверджувати, що найбільш придатним видається інтегративний підхід. Такий підхід дозволить поєднати в єдине ціле окремі елементи кожного із описаних підходів, для досягнення ефективних показників психологічної готовності майбутніх офіцерів-психологів до професійної діяльності.

У рамках даного підходу вважаємо можливим здійснити визначення та обгрунтування основних критеріїв психологічної готовності майбутніх офіцерів-психологів до професійної діяльності. 
Критерії, або показники, на підставі яких можна визначити рівень готовності фахівця до професійної діяльності, на думку М. Дмітрієвої, можуть бути: зовнішніми стосовно людини (об'єктивними) і внутрішніми (суб'єктивними). До першої групи критеріїв входять такі показники результативності діяльності, як кількість і якість виробленої продукції, продуктивність тощо. У другу групу можуть бути включені: професійно важливі якості, професійні знання, уміння i навички; професійна мотивація; професійна самооцінка і рівень домагань; здатність до саморегуляції і стресостійкість; особливості професійної взаємодії; загальна фізична тренованість [5].

За визначенням В. Рибалки психологічна готовність особистості до діяльності формується 3 п’яти ключових компонентів: потребово-мотиваційного, інформаційно-пізнавального, цілеутворюючого, результативного та емоційнопочуттєвого [14, с. 43].

Ф. Рекешева розглядає психологічну готовність до професійної діяльності як відносно стійку і специфічну для конкретного виду діяльності систему психологічних властивостей особистості, що зумовлює досягнення адекватного вимогам діяльності результату і є умовою для саморозвитку й самореалізації людини засобами професійної діяльності.

На підставі цього виділяє кілька рівнів професійних якостей фахівця, які виступають критеріями розвитку психологічної готовності до професійної діяльності психолога:

- особистісна готовність: автономність (самостійність, незалежність); інтернальність (внутрішній локус контролю); адекватна самооцінка; інтегрованість ціннісно-мотиваційної сфери (відсутність виражених внутрішніх конфліктів); гуманістична спрямованість особистості;

- когнітивно-операційна готовність: загальні інтелектуальні здібності; вербальна креативність; здатність до рефлексії; прагнення до пізнання та саморозвитку; успішність професійного навчання;

- емоційно-вольова готовність: емоційна стійкість, урівноваженість; здатність до саморегуляції та самоорганізації; цілеспрямованість; наполегливість;

- інтерактивна готовність: соціальний інтелект, комунікативні здібності, прийняття інших, комунікативна толерантність, емпатійні здібності;

- внутрішня моральна організація особистості, яка полягає в усуненні у процесі самовдосконалення суперечності між «Я»-реальним та «Я»ідеальним [15].

Л. Лежніна визначила інтегральні й конкретні критерії готовності психолога до професійної діяльності. Група інтегральних критеріїв представлена двома підгрупами:

- критерії готовності абітурієнта до навчально-професійної діяльності психологічного напряму (внутрішньо усвідомлені мотиви вибору професії психолога, соціальний інтелект, емпатія, якість загальноосвітніх знань та вмінь продуктивної навчально-пізнавальної діяльності); 
- критерії готовності випускника до професійної діяльності психолога (професійна спрямованість, інтернальність та професійна підготовленість).

Конкретними критеріями готовності, на думку науковця, є компетенції як сукупність знань, умінь і якостей, які забезпечують здатність вирішувати професійні завдання. Автор виділяє десять видів ключових компетенцій психолога, диференційованих у три групи:

- компетенції психолога як особистості й суб'єкта життєдіяльності: компетенції здорового способу життя, ціннісно-смислової орієнтації у світі, інтеграції, громадянської позиції, самовдосконалення, саморозвитку;

- компетенції, що стосуються соціальної взаємодії психолога в соціальній сфері: компетенції соціальної взаємодії, компетенції у спілкуванні;

- компетенції, які стосуються конкретної діяльності психолога: компетенції професійної діяльності (загальнопрофесійні та спеціальні, що відповідають психологічній структурі діяльності), інформаційних технологій та ін. [10].

Т. Ковалькова при визначенні критеріїв та показників готовності майбутніх психологів до професійної діяльності в авіаційній галузі визначає наступні критерії:

- особистісний критерій - відображає рівень особистісної готовності до професії та характеризує розкриття студентами особистісного сенсу обраної професії, розвиток уявлень про себе як про суб'єкта професійної діяльності (образ «Я - психолог»);

- когнітивний критерій - характеризує рівень сформованості психологічних знань та системи уявлень студентів про майбутню професійну діяльність (образ професіi);

- інтерактивний критерій - відображає рівень сформованості інтерактивної готовності майбутніх психологів, що визначається професійними уміннями та здатністю застосовувати психологічні знання для виконання своїх обов'язків: конкретні дії, прийоми, психологічні «техніки»;

- рефлексивний (оцінний) критерій передбачає самооцінку своєї професійної підготовки та відповідність процесу розв'язання професійних завдань особливостям діяльності психолога [8].

Доречним, також видається аналіз поглядів сучасних українських науковців щодо компонентів та критеріїв психологічної готовності до професійної діяльності, яка здійснюється в особливих та екстремальних умовах.

Так, В. Молотаєм було визначено наступні критерії психологічної готовності військовослужбовців Внутрішніх військ МВС України до службово-бойової діяльності: 1) усвідомлення військовослужбовцем соціального та особистісного сенсу участі у службово-бойовій діяльності; 2) стійкість та адаптивна врегульованість дій; 3) своєчасність і доцільність оперативних службово-бойових дій; 4) адекватність дій правоохоронним нормам і умовам службово-бойових ситуацій [11]. Наведені автором критерії психологічної готовності, лише частково можна визначити як справді психологічні (усвідомлення соціального та 
особистісного сенсу, стійкість та адаптивна врегульованість) інші стосуються скоріше професійної компетентності фахівця.

У психологічній готовності офіцерів пожежної охорони до професійної діяльності О. Бикова виділяє 5 основних критеріїв та характеризує їх компоненти:

1) морально-психологічна готовність (компоненти: мотиваційний, морально-орієнтаційний, пізнавально-операційний, емоційно-вольовий, психо-фізіологічний, оцінно-змістовий);

2) командирська готовність (компоненти: природний талант лідера, розуміння соціальної значущості бойового завдання, відповідальність, інтуїція, висока творча активність, оптимізація своєї управлінської діяльності, сміливість, рішучість, врівноваженість, упевненість, переконливість, чіткі команди, оперативність прийняття рішення, готовність до ризику);

3) авторитативна готовність (компоненти: спонукальний, регулятивний, трансформативний, інформаційно-пізнавальний, регенеративний, виховальнодисциплінуючий, морально-етичний, авторитетно-престижний, посадовий, управлінський, лідерський, харизматичний);

4) креативна готовність (компоненти: генератор ідей, евристична творча діяльність, професійне честолюбство, інсантність, дивергентність, пошук, гнучкість розуму, наукова комунікабельність, глибина знань і ємність тезаурусу, високий науковий авторитет);

5) комунікативна готовність (компоненти: психологічна сумісність, активна життєва позиція, відданість обов'язку, єдність поглядів 3 колективом, професійне товариство, взаємодопомога, повага до колег, до правил співжиття, здатність до самовиховання, самокритичність, відсутність егоцентризму, здатність до спілкування, володіння професійною мовою, ситуаціями професійного мовлення) [2].

О. Кокун у психологічній готовності фахівця до діяльності в екстремальних умовах виділяє дві основні складові: особистісну і функціональну готовність, кожна з яких передбачає наявність певних критеріїв та відповідних показників. Особистісна готовність включає в себе: моральну, вольову, комунікативну та загальнопсихологічну готовність. Відповідно, до складу функціональної готовності, автор включає мотиваційну, когнітивну, креативну, орієнтаційну, операційну та оцінювальну готовність із відповідними показниками [9].

Висновки. На основі вищенаведеного аналізу основних підходів, критеріїв та показників, психологічну готовність майбутніх офіцерів- психологів до професійної діяльності можна визначити як інтегративне утворення яке мобілізує внутрішні особистісні ресурси та забезпечує психологічну придатність до діяльності.

Теоретичне осмислення основних підходів до формування психологічної готовності майбутніх офіцерів-психологів до діяльності дозволяє стверджувати, що найбільш вдалим виступає інтегративний підхід, в межах якого виокремлюємо особистісну, функціональну та спеціальну готовність.

Особистісна готовність передбачає наявність наступних компонентів та їх показників: 
- психологічної готовності (особистісна автономність, адекватна самооцінка та рівень домагань, адекватний рівень особистісної тривожності, здібності до саморегуляції та самоконтролю, комунікативні здібності тощо);

- мотиваційної готовності (усвідомлений мотив вибору професії, професійна спрямованість, потреба у самовдосконаленні та досягненні успіху при вирішенні професійних завдань, цілеспрямованість тощо);

- когнітивної готовності (сформована система уявлень про майбутню професійну діяльність, рівень інтелектуальних здібностей, усвідомлення своїх здібностей та можливостей, прагнення до пізнання та саморозвитку, наявність професійних (психологічних) знань, умінь та навичок тощо);

- моральної готовності (усвідомлення соціального та особистого сенсу професійної діяльності, відповідальність, людяність, активна життєва позиція, гуманістична спрямованість особистості тощо);

- емоційно-вольової готовності (психологічна стійкість та врівноваженість, здатність до саморегуляції, самоорганізації, самоконтролю, наполегливість, організованість, готовність до ризику, рішучість, сміливість, впевненість у собі тощо).

До функціональної готовності належать наступні компоненти:

- комунікативна готовність (загальні та професійні комунікативні якості: емпатійність, комунікабельність, рефлективність, володіння професійною мовою та комунікативними технологіями, готовність до взаємодії та взаємодопомоги, комунікативна толерантність тощо);

- креативна готовність (гнучкість розуму, здатність генерувати ідеї, творчі здібності, евристичність, інсайт, інтуїція, творча активність, тощо);

- операційна готовність (наявність умінь та навичок для вирішення професійних завдань, оволодіння способами і прийомами професійної психологічної діяльності (прийомами, техніками, технологіями, здатність до моделювання діяльності тощо);

- оцінювальна готовність (здатність до рефлексії, самокритичність, самооцінка своєї професійної підготовки та відповідність результату вирішення завдань визначеним професійним вимогам тощо).

Спеціальна готовність включає такі компоненти:

- військову готовність (здатність до виконання спеціальних військових завдань та несення військової служби, здатність до ризику, швидкість прийняття рішень, мобілізованість, рішучість, рівень військово-технічних знань тощо);

- командирська готовність (наявність лідерських здібностей, дисциплінованість, здатність до самопожертви, відповідальність, вміння переконувати, рішучість, вміння прогнозувати ситуацію, вимогливість до себе та інших, вміння швидко орієнтуватись у ситуації, патріотизм тощо);

- синергетичну готовність (висока здатність до самоорганізації, самоконтролю та самоефективності, здатність до саморегуляції та відновлення психічної стійкості, застосування прийомів саморозвитку і самовдосконалення тощо). 
Перспективами подальшого дослідження $\epsilon$ емпіричне вивчення особливостей психологічної готовності майбутніх офіцерів-психологів до професійної діяльності, дослідження гендерних особливостей психологічної готовності майбутніх офіцерів-психологів до професійної діяльності.

1. Ананьев Б. Г. Психологическая структура человека как субъекта. Человек и общество : научно-практ. журнал / гл. ред. Б. Ф. Ломов. Ленинград : ЛГУ, 1967. Вып. 2. С. 235-249.

2. Бикова О. В. Формування готовності до професійної діяльності майбутніх офіцерів пожежної охорони : автореф. дис. ... канд. пед. наук : 13.00.04. Київ, 2001. 21 с.

3. Василенко Е. В. Формирование профессионально-психологической устойчивости будущих сотрудников ОВД к экстремальным ситуациям : дис. ... канд. психол.наук : 19.00.07. Ставрополь, 2008. 229 с.

4. Гребенюк Г. С. Мотиваційна готовність курсантів і слухачів вищого військового учбового закладу до професійної діяльності (на прикладі спеціалістів пожежної безпеки МВС України) : автореф. дис. ... канд. психол. наук. Київ, 1997. 17 с.

5. Дмитриева М. В. Психологический анализ системы «человек-профессиональная среда». Вестник ЛГУ имени А. С. Пушкина. Серия Философия, политология, социология, психология, право, международные отношения : журнал / гл. ред. В. С. Скворцов. 1990. Вып. 1. № 6. С. 82-90.

6. Дружинин В. Н. Психология общих способностей. Санкт-Петербург : Питер, 2002. 368 с.

7. Карамушка Л. М. Психологія управління закладами середньої освіти : монографія. Київ : Ніка центр, 2000. 332 с.

8. Ковалькова Т. О. Діагностичний інструментарій щодо перевірки ефективності підготовки майбутніх психологів до професійної діяльності в авіаційній галузі. Наукові записки Національного педагогічного університету ім. М. П. Драгоманова. Серія : Педагогічні та історичні науки. 2012. Вип. 108. С. 76-80.

9. Кокун О. М. Зміст та структура психологічної готовності фахівця до екстремальних видів діяльності. Проблеми екстремальної та кризової психології : збірник наукових праць. Київ, 2010. Вип. 7. С. 182-190.

10. Лежнина Л. В. Готовность психолога образования к профессиональной деятельности: этапы, механизмы, технологии формирования : автореф. дис. ... д-ра психол. наук. Москва, 2009. 20 с.

11. Молотай В. А. Формування психологічної готовності військовослужбовців внутрішніх військ МВС України до діяльності по охороні громадського порядку : автореф. дис. ... канд. психол. наук. Хмельницкий. 2006. 20 с.

12. Мул С. А. Психологія готовності офіцера-прикордонника до професійної діяльності : дис. ... д-ра наук із загальна психологія, історія психології : 19.00.01 / Нац. б-ка України ім. В. І. Вернадського. Київ, 2016. 539 с.

13. Полюк В. С. Інтегративна модель професійної готовності майбутніх офіцерів. Збірник наукових праць Хмельницького інституту соціальних технологій Університету «Україна». 2013. №1 (7). С. 185-188.

14. Рибалка В. В. Особистісний підхід у профільному навчанні старшокласників : монографія. Київ : ІПППО АПН України, 1998. 160 с.

15. Рекешева Ф. М. Условия развития психологической готовности к профессиональной деятельности студентов-психологов : автореф. дис. ... канд. психол. наук. Астрахань, 2007. $20 \mathrm{c}$.

16. Сердюк Л. Зміст та структура психологічної готовності до професійної діяльності студентів з інвалідністю. Освіта Регіону : украӥнський науковий журнал. №5. 2011. С. 140-144.

17. Стаднік А. В., Ващенко І. В., Васищев В. С. Теоретико-методологічні національної гвардії України до службово-бойової діяльності. Вісник ХНПУ імені Г. С. Сковороди. Психологія. 2017. Вип. 55. С. 250-258. 
18. Торічний О. В. Теорія і практика формування військово-спеціальної компетентності майбутніх офіцерів-прикордонників у процесі навчання. Хмельницький : Вид-во Національної академії ДПСУ, 2012. 535 с.

19. Ягупов В. В. Військова психологія : підручник. Київ : Тандем, 2004. 656 с.

УДК 159.9: 378-051

doi: 10.15330/psp.22.115-122

Галина Дубчак

\section{АНАЛІЗ ОСОБИСТІСНИХ РЕСУРСІВ ПРОФЕСІЙНОЇ СТРЕСОСТІЙКОСТІ ФАХІВЦІВ СОЦІОНОМІЧНИХ ПРОФЕСІЙ}

У статті обтрунтовано актуальність вивчення проблеми особистісних ресурсів професійної стресостійкості фахівиів соиіономічних професій. Розкрито зміст поняття «професійна стресостійкість». Представлено результати емпіричного дослідження особистісних ресурсів професійної стресостійкості студентів, щчо навчаються за соціономічними професіями та працюючих фахівців, визначено їх спільні та відмінні особливості. Виявлено, шуо для студентів закладів вищзї та середньої освіти характерним є низький та середній рівень психічної напруги, тоді як поведінка фахівиів характеризується більшою стресогенністю, високим рівнем ресурсності. Відзначено, що адаптаційні можливості людини і стійкість до стресогенних життєвих обставин обумовлені типом особистості, в якій провідну роль відіграють особистісні (сочіально-психологічні) ресурси.

Ключові слова: професійна підготовка, соціономічні професії, стрес, професійна стресостійкість, рівень психічної напруги.

The article substantiates the relevance of studying the problem of professional stress resistance of specialists of socionomic professions. The content of the concept "professional stressresistance» is explained. The paper presents the results of the empirical study of individual resources of professional stress resistanse students of socionomic profile and working professionals. There were determined the common and distinctive features of stress resistance of future and working specialists of various socionomic professions. It was found that for students of institutions of higher and secondary education characterized by low and average level of mental stress, while the behavior of specialists is characterized by greater stress-relatedness. Specialists have a high level of resource efficiency. It has been established that adaptive human capacities and resistance to stressful life circumstances are caused by the type of personality, in which the personal role (social-psychological) resources plays a leading role.

Keywords: professional training, socionomic professions, stress, professional stress resistance, level of mental tension.

\section{Постановка проблеми у загальному вигляді та їі зв'язок із важли-} вими науковими і практичними завданнями. Проблематика стресостійкості людини в різних професіях 3 давніх часів привертала увагу психологів різних напрямків. У дослідженнях багатьох авторів показано, що тривалий вплив стресу призводить до таких несприятливих впливів, як зниження загальної психічної стійкості організму, появи почуття незадоволення результатами своєї діяльності, тенденції до відмови від виконання завдань у ситуаціях підвищених вимог, невдач і поразок. Тому стресостійкість визнається одним із факторів, що впливає на ефективність професійної діяльності. 3 іншого боку, успішна профе- 